\title{
The Causes of the Lack of Independent Personality of Contemporary College Students and Its Educational Countermeasures
}

\author{
Han Shuai \\ College of Marxism, Xi'an University of Science and Technology, Xi'an, P. R. China \\ Email address: \\ 361938397@qq.com \\ To cite this article: \\ Han Shuai. The Causes of the Lack of Independent Personality of Contemporary College Students and Its Educational Countermeasures. \\ Teacher Education and Curriculum Studies. Vol. 6, No. 1, 2021, pp. 23-27. doi: 10.11648/j.tecs.20210601.15
}

Received: February 21, 2021; Accepted: March 4, 2021; Published: March 12, 2021

\begin{abstract}
Only with independent personality can we have inner freedom, spiritual independence, our own judgment standard and rational judgment. Independent personality is a mature expression of a person. Independent personality is also an important manifestation of a country's civilization progress. Independent personality embodies the independence of personality and affects a person's thought and behavior. The lack of independent personality will lead to problems in college students' studies, life and emotion. Because the cultivation of independent personality of college students is very urgent, can be said to be urgent. In school education, social education, family education pay attention to the overall development of college students, in self-education pay attention to their own promotion, then it is possible to become a mature, stable, full of self-esteem, self-confidence, self-love and independent college students, can truly adult and become the pillars of society. Only with independent personality can we have inner freedom, spiritual independence, our own judgment standard and rational judgment. Independent personality is a mature expression of a person. Independent personality is also an important manifestation of a country's civilization progress. This paper discusses the reasons for the lack of independent personality of college students from four aspects: society, school, family and self, and puts forward some research countermeasures from these four aspects.
\end{abstract}

Keywords: Contemporary College Students, Independent Personality, Research Countermeasures

\section{Introduction}

University is the key period for the cultivation and formation of independent personality. For college students, independent personality is not only the basis for them to form a good mind and obtain good learning ability, but also the necessary factor for the future development of society. Additionally, to clarify the location of these strategies in the broader framework of personality structure. Neuroticism-Anxiety contributed mostly to strategies focused on emotions, acceptance and denial. [1] If college students want to form independent personality, they should try their best to guide and overcome neuroticism-anxiety to form good emotions and understand how to accept and deal with problems.

Personality does not have a recognized definition, different psychologists, because of their different focus on personality, the definition of personality is also different. American psychologist Poven believes that personality provides direction and mode for individual life, represents the general characteristics of individuals or people, and shows that the reflection of situation can be a lasting model. Huang Xiting believes that personality is the internal tendency of individuals in behavior. It is expressed as the integration of ability, emotion, need, motivation, interest, attitude, values, temperament, character and system when individuals adapt to the environment [2]. Zheng Xue believes that personality is a relatively stable and unique psychological behavior pattern formed by the interaction of individuals with acquired environment on the basis of genetic quality. Based on the above analysis, we believe that personality is a self-consciousness, a state of self-existence, and has a clear self-cognition. If you use an easy-to-understand word to generalize, it is "personal existence state ". That is to say, a person's personality is determined according to his state of existence. If a person can maintain an independent state of existence, then the personality of the person is sound, which can be called "independent 
personality "; conversely, if a person is attached to others and exists, then the personality of the person is unsound, which can be called" dependent personality ".

The so-called independent personality refers to the independence, autonomy and creativity of people. It requires people to rely neither on any external spiritual authority nor on any realistic political force, to have independent judgment ability in the pursuit of truth, and to have independent spirit in political participation. Personality independence, manifested as habit independent thinking, independent practice, have a strong rational ability. Man is a man because he is free, he can choose his own way of life, he is his own master. This self-consciousness and autonomous behavior constitute a person's independent personality. Independent personality, not necessarily to deliberately pursue different, but to pursue what they want to pursue and willing to pay for it. Independent personality, is a vitality, give people a broad space for growth. Independent personality is like human skeleton, tree foundation, no independent personality, a person is like a puppet. Only with independent personality can we have inner freedom, spiritual independence, our own judgment standard and rational judgment. Independent personality is a mature expression of a person. Independent personality is also an important manifestation of a country's civilization progress.

\section{The Performance and Causes of the Lack of Independent Personality of College Students}

\subsection{Performance of Independent Personality Deficit in College Students}

Nowadays, the development of market economy, the overall acceptance of foreign ideas and the diversification of ideas bring about the confusion of college students' thoughts. Nowadays, college students are only children, most of them lack the ability of independence. Because of the lack of independent personality, many college students have various problems. In July 2004, a survey by China Youth Daily showed that 14 percent of college students had depressive symptoms, 17 percent had anxiety symptoms and 12 percent had hostility. [3]

\subsubsection{Lack of Ability to Think Independently}

In today's college campus, many college students are used to replacing their own experience with the experience of others, replacing their own thinking with the thinking of others, and accepting the views and opinions of others without thinking and discrimination. Most college students dare not have their own ideas. In the crowd, most people think that without expressing any views and opinions, they will gain a "sense of security". At the same time, in today's university campus, the phenomenon of cheating in exams has been repeatedly prohibited, and even think that college exams should be temporary cramming, think that everyone cheats, so I also want to cheat. The homework submitted to the teacher is also the same, without any thinking. The most important reason is that college students lack the ability to think independently. Besides, the personality of some college students shows addictive behavior [4], such as game addiction, which is contrary to and contradictory to the formation of independent personality, which is a self-disciplined personality, and addictive behavior is just immature, undisciplined performance.

\subsubsection{Lack of Ability to Deal with Problems Independently in Life}

Nowadays, most college students are only children, the family conditions are constantly improved and improved, and the parents' indulgence to their children leads to the lack of life experience, strong dependence, poor autonomy and lack of ability to deal with problems independently. Some college students can not normally integrate into college life after entering university, which is very unsuitable for college life, and very few college students lack the most basic ability to take care of themselves. For example, college students post to help others sew shirt buttons, college students send dirty clothes home, college students hire nannies, life problems to call their parents. These all show that some college students have poor self-care ability and rely heavily on their parents. Although the above cases can not fully reflect the self-care ability of the whole college students in today's society, they have to admit that in the contemporary college students, there are not a few people with weak self-care ability. They tend to retreat and show no opinions, which restrict the formation and development of independent personality. For the relationship between students, students get along with each other, there are different problems among college students, such as the Ma Jia Jue incident in 2004, the Lin Senhao poisoning incident in 2013, Ma Jia Jue and Lin Senhao are both introverted people. Problems with students are not dealt with in time, and eventually lead to tragedy.

\subsubsection{Lack of Independence in Emotion}

Nowadays, many college students think that love is a compulsory course in college, they think that college must have a love, not love is a failure. Through the "performance" of love in the eyes of others to obtain self-affirmation, this is a lack of autonomy. Some college students regard love as a kind of "performance", which can obtain inner satisfaction. Some college students because of lovelorn or love frustration, they thought of suicide, but also regrettable. In 2002, 27.8\% of college suicides in Shanghai, $22 \%$ of them were induced by love, $5.6 \%$ by health reasons, $11.1 \%$ by mental illness and $5.6 \%$ by others. The Nanjing Crisis Intervention Center also found that love problems accounted for $44.2 \%$ of college students' suicide. On the one hand, many college students regard love as a "performance ", on the other hand, some college students think of suicide because of lovelorn or frustrated love.

\subsection{Causes of the Lack of Independent Personality of College Students}

\subsubsection{For School}

Mr. Cai Yuanpei, the first president of Peking University, put forward at the beginning of the 20th century:" The basic policy of national education is to develop the sound personality of the 
republic." Mr. Chen Yinke wrote on Mr. Wang Guowei's tombstone: "Independent personality, the spirit of freedom", which is his mind of the university spirit, that is, the responsibility of the university. Therefore, the fundamental of school education should be to cultivate students' sound and independent personality. Personality factors, students' resilience and achievement values play an important role in learning progress, learning and individual differences. [5]

\subsubsection{For Family}

The roles of parents and teachers play an important role in the formation of students' personality. [6] Nowadays, college students take the post-95s as the main body, as single children, the environment of growth is arranged, parents will take care of the only child completely, control or replace the children to make all decisions, unconsciously doting on the children, children have been deprived of hands-on exercise opportunities, self-care is constantly weakening, independent personality is constantly missing. Under the examination-oriented education, the parents are all "looking forward to the son" mentality, the parents arranged the children to do all the students' affairs at home, the children's task is only to study, but this is not conducive to the formation and development of independent personality of college students.

\subsubsection{For Society}

Marxism holds that man is the sum of social relations and the product of social environment. The long-term feudal autocratic rule bound the thought, caused the individual personality selfatrophy, the independent consciousness is not strong, generally lacks the independent personality. Chinese scholars used the revised "California Psychological questionnaire "(CPI) to investigate 1100 college students in 16 colleges and universities, such as Tsinghua University, Peking University and Beijing normal University, and found that Chinese college students have the characteristics of steady personality and good degree of socialization. But their scores for "independent achievement" and flexibility were low. Since the reform and opening up, the development of market economy and the globalization of economy have led to the sharp expansion of egoism, liberalism, money worship and extreme individualism. It leads to the loss of college students' belief, the loss of value, the confusion of ideas, the spread of extreme individualism, the extreme fragility of their hearts, the commercialization of interpersonal relations, and so on. A study has shown that a person's independent personality is related to many factors, and in society, a person's attitude to tipping is influenced by his own psychology. Knowledge about the personality predictors of tipping attitudes, motives, and behaviors could shed light on the psychological processes underlying tipping and might allow service workers to better predict and manage their tip incomes. [7] In short, a person's behavior is related to his personality.

This negative effect of economic globalization spreads to colleges and universities, which will inevitably change the ideological consciousness and values of college students who are not deep in the world and have weak ability to distinguish right from wrong, and make their social value system change, thus leading to the lack of independent personality of college students.

\section{Analysis on Educational Countermeasures of Independent Personality of Contemporary College Students}

As the talents who receive higher education scientifically, the comprehensiveness and harmony of their independent personality are mainly reflected in: being loyal to truth, emancipating the mind, harmonious personality, open-mindedness; having a sound self-consciousness, full of self-esteem, self-confidence, self-love, and firmly dominating their own destiny; being independent and special, not attached to power, not attached to others, not committed to perfection, disobedient, not following the tide, let alone clinging to the dragon, servile and so on. [8]

So how to cultivate the independent personality of college students, here are some feasible ways:

\subsection{Schooling}

Some researches show that there is a close relationship between lecturer's personality and students' motivation to learn and read, and teachers influence the formation of students' personality [9]. Over the years, our school has a clear tendency: attach importance to collectivism education, ignore the cultivation of self-consciousness, attach importance to the discipline of rules and regulations on students, ignore the development of personality psychology. Respect for students' personality is a prerequisite for the development of students' independence. Now that the reform and opening up have been for decades, President Xi mentioned in his previous speech that the younger generation has ideals and responsibilities, that the country has a future, and that the nation has hope. Then the purpose of school education is to train students to become ideal and responsible college students. The concrete method is to perfect and optimize the educational goal, reform and enrich the teaching content, improve and innovate the teaching method, train and strengthen the teaching staff and so on. College students have five personality traits (extraversion, agreeableness, conscientiousness, neuroticism, and intellect/imagination). These results provide evidence that students with different personality traits have different preferences for and experiences in online courses [10]. Rick Dalton pointed out that colleges in rural America play an important role in efforts to promote student success [11]. Therefore, school education plays an important role in the formation of students' independent personality.

\subsection{Social Education}

Social education is an important part of life education. Good social order and social environment can promote the healthy growth of college students. Simply put, social education is to help a person through education to successfully complete the process of socialization. Social education includes establishing social consciousness, forming social concept, shaping social character, cultivating social ability, 
learning social norms, understanding social culture and integrating into social life. It is to help a person form a correct outlook on life and society. With family education and school education. The influence of social education is greater and farther. In social education, we can use mass media, such as meetings, radio stations, windows, websites, seminars, special journals and other ways and means to vigorously promote the correct outlook on life and values in the whole society. Imagery determination of commitment to the country as part of the socio-psychological capital of the personality of students. [12]

\subsection{Family Education}

Family education plays a very important role in the process of a person's growth. Because of the far-reaching influence of examination-oriented education, most parents are looking forward to success, and their parents have not completed their dreams. Children lose their right to independence. Pay attention to the cultivation of parents' independent ability to children in family education, do not overindulge and protect, give their children free growth space, do not impose their own ideas and wishes on their children. Nowadays, the competition in this society is fierce, which requires everyone to develop in an all-round way, so parents should let their children grow up independently, give their children some time and space to grow up, and pay more attention to their all-round development ability. Only by encouraging children to develop in an all-round way can they be based in society and vice versa.

\subsection{Self-education}

It has been proved that the meaning of life, personal growth initiative, life orientation and wisdom are closely related to students'real personality. [13] When faced with problems, the first to analyze themselves, Confucius said: my three provinces my body. Lu Xun said: I sometimes dissect others, but often more strictly dissect themselves. Comprehensive and objective understanding of themselves, at the same time a comprehensive understanding of the problem. Ask yourself if you have the ability to solve this problem and how to solve it. Fully understand yourself, you can know how to solve this problem. Inner analysis can understand the real self, only the real understanding of their own people will make a decision to their satisfaction. Undergraduate students (83 males and 92 females) whose average age was $20(\mathrm{SD}=5.1)$ completed questionnaires on demographic characteristics, mobile phone use, impulse control, and big five personality traits. Hierarchical regression analyses were conducted to examine whether each personality trait mad. [14]

As college students, they should have ideals and aspirations. President Xi said that the younger generation has ideals and responsibilities, the country has a future, and the nation has hope. Li Junwei, a professor at the Marxism Teaching and Research Department of the Central Party School, said:" Young people establish their ideals and goals. From the relationship between people and society, lofty ideals mean that young people should shoulder the mission of the country and society, care for the fate of the nation and the country, and be a capital person. It is because of such a group of responsible and responsible young people that the country and society have hope." Therefore, a study tests the hypothesis that personality raits, and Neuroticism in particular, predict alcohol use/misuse in matriculating freshmen above and beyond reported levels of stress. Methods Data were collected as part of an IRB-approved longitudinal study, examining college students' behavioral health. Participants were 303 first-year college students $(70 \%$ female) with an average age of 18.58 (SD = 0.39) [15]. This test shows that the behavior of college students is linked to many factors, and drinking alcohol can also affect the health behavior of college students. However, contemporary college students with lofty ideals and aspirations can become the tide of this society.

\section{Conclusion}

The confusion and problems of college students in their studies, life and emotion are closely related to the lack of independent personality of college students. A college student with independent personality can better realize himself, better adapt to society and better build the motherland. Nowadays, it is very urgent to cultivate college students with independent personality. In school education, social education, family education pay attention to the overall development of college students, in self-education pay attention to their own promotion, then it is possible to become a mature, stable, full of self-esteem, self-confidence, self-love and independent college students.

\section{References}

[1] Gomà-i-Freixanet Montserrat; Martínez Ortega Yolanda; Arnau Anna. The location of coping strategies within the Alternative Five Factor Model of personality, Volume 60, 2021.

[2] Huang Xiting. Mental Health Education for College Students, East China Normal University Press, pp. 41, 2004.

[3] Zheng Xue. psychology of personality, Jinan University Press, pp. 6-7, 2004

[4] Natalia N. Bessonova; Vera S. Butenko; Natalia A. Gudz; Anna M. Kukulyar. Research of psychological features of the personality of students exhibiting addictive behavior, SHS Web of Conferences, Volume 70, 2019.

[5] Julia Backmann; Matthias Weiss; Michaéla C. Schippers; Martin Hoegl. Personality factors, student resiliency, and the moderating role of achievement values in study progress Learning and Individual Differences, Volume 72, 2019, PP 39-48.

[6] Leni Marlina; Delvi Wahyuni; Fitrawati Fitrawati. Correlation of Lecturers'personality and Students'Motivation in Learning Reading Courses at English Language Universitas Negeri Padang, Proceedings of the Sixth of International Conference on English Language and Teaching (ICOELT 2018), 2019.

[7] Lynn Michael. Effects of the Big Five personality traits on tipping attitudes, motives, and behaviors, International Journal of Hospitality Management, Volume 92, 2021. 
[8] Zhang Xiaotao. College Students' Spiritual Adult: Why and What, Modern Education Management, pp. 97-98, 2011 (9).

[9] Bhagat Kaushal Kumar; Wu Leon Yufeng; Chang Chun Yen. The impact of personality on students' perceptions towards online learning, Australasian Journal of Educational Technology, Volume 35, Issue 4, 2019.

[10] Rick Dalton. Rural America's Pathways to College and Career: Steps for Student Success and School Improvement, Taylor and Francis, 2021.

[11] Agatha Kaushal Kumar; Wu Leon Yufeng; Chang Chun Yen. The impact of personality on students' perceptions towards online learning, Australasian Journal of Educational Technology, Volume 35, Issue 4, 2019.

[12] Svetlana Frolova. Imagery determination of commitment to the country as part of the socio-psychological capital of the personality of students, SHS Web of Conferences, Volume 70, 2019.
[13] Farzad Ghaderi; Koroush Namdari; Shabrooz Ghobadi; Mozhgan Shokroolahi. The structural relationship of meaning in life, personal growth initiative, life orientation and wisdom with authentic personality in students, Shenakht Journal of Psychology and Psychiatry, Volume 6, Issue 5, 2019, PP 55-71. Masahiro Toyama; Yusuke Hayashi. Links of personality traits to media multitasking: Conscientiousness predicts mobile phone use in the college classroom, Current Psychology, pp. $1-8,2021$

[14] Dr. Syed Afzal Shah; Dr. Habib Elahi; Dr. Sadaf Naz. Effect of Pakistani Parental Role and Teachers'Role on the Neuroticism Personality of Students, Open Journal of Statistics, Volume 3, Issue 2, 2020, PP 76-82.

[15] The Validity of the Personality Assessment Inventory-Adolescent in Assessing Callous-Unemotional Traits in At-Risk Adolescents, Journal of Personality Assessment, Volume 103, Issue 1, 2021, PP 48-56. 